\title{
Activity of Orange (Citrus Sinensis) and Lemon (Citrus Limon) Juice and Oil on Different Bacteria That Cause Wound Infection
}

\author{
Abdulaziz Aburowais", Afreen Banu, Mehru Nisha
}

\begin{abstract}
The antibacterial activity of Citrus sinensis and Citrus limon was evaluated on bacterial strains. Juice and oil were used by agar disc and well diffusion. The antibacterial effects of Citrus oil were found to be effective using disc method among all strains, except Clostridium spp, which was found no inhibition with Citrus sinensis oil. However, Clostridium spp with Citrus limon oil had inhibitory zone $(7 \pm 0 \mathrm{~mm})$, while the remainder of organisms, it showed moderate zones of inhibition ranging from $6-9.66 \mathrm{~mm}$ in diameter. By well diffusion method, it showed highest zone of inhibition on S. aureus, which was $12 \mathrm{~mm}$ in diameter, while on the other organisms with Citrus it showed little or no zones of inhibition ranging from $0-6 \mathrm{~mm}$ in diameter.The juice from C.limon juice exhibited inhibitory activities against bacteria in using the disc method except for S. pyogenes, which was found no inhibition, while other organisms, it showed moderate zones of inhibition ranging from $6.66-12 \mathrm{~mm}$ in diameter.Citrus sinensis juice showed no inhibition against bacteria.The results obtained in this study suggested that Citrus limon had overall better antibacterial activity compared to Citrus sinensis.
\end{abstract}

Keywords - Citrus Sinensis, Citrus Limon, Disc Diffusion, Well Diffusion

\section{INTRODUCTION}

Citrus is one of the most important fruit grown in many countries of the world. Orange and lemon are an important medicinal plant of the family Rutaceae. They are cultivated for long time age, for dietary intake, as well as to be used as herbal medicines. This is mainly for their content of alkaloid which is present in all parts of the plant (edible part, leaves, steam, roots, or flower) of citrus against clinically significant bacterial strains [9]. Usually in industries, orange fruits are processed alone, while peels are considered to be redundant. However, the orange peel contain a large quantity of nutrients and other important chemicals such as flavonoid, glycosides, coumarins, sitsterols, glycosides and volatile oils that can be used in food and medicine [19]. In addition, the fiber of citrus fruit also contains bioactive compounds, such as polyphenols. The most medically significant use of orange is to treat scurvy disease, due to high content of vitamin $\mathrm{C}$ in orange fruit. [1],

Abdulaziz Aburowais*, Department of Biotechnology, Faculty of science, Lincoln University College, Malaysia, aborws2010@gmail.com

Afreen Banu, Department of Microbiology, Faculty of Medicine, Lincoln University College, Malaysia,

Mehru Nisha, Department of Clinical laboratory science, Faculty of Medical science technology, University Kuala Lumpur.
[10]. In addition, many studies reported its antioxidant and antibacterial effects of the juice and edible part of lemon and orange [6]. Currently, drug resistance issue against commonly used antibiotic is the main problem to treat bacterial related diseases. This is due to the ability of bacteria to transmit and acquire resistance to those drugs [13].To overcome this problem, researchers, scientists, pharmacological companies and industries are in rush to find new alternatives. One of their investigations is on how to use lemon and orange contents as an antibacterial substance. Throughout the mankind history, several infectious diseases have been known to be treated with herbal medicine, because of medicine content of herbal extracts [16], [17]. This opened the door for prominence of discovering in this field. This study look into the possibilities of using lemon and orange to treat wound infections. It aims to evaluate antimicrobial activity of citrus on selected pathogens obtained from wound infections.

\section{MATERIALS AND METHODS}

\section{Materials}

Equipment: Autoclave, Electronic weighing balance, Hot-air oven, Refrigerator,

Compounds: orange oil (Korean company), lemon oil (Purchased from local mall in Malaysia) and orange and lemon juice (Purchased from local mall)

Culture media: Mueller-Hinton agar, Nutrient agar, chocolate agar and blood agar.

Antibiotic disc: Amoxicillin-Clavulanic acid, Gentamicin, Streptomycin and Tetracycline.

\section{Citrus oil and juice}

Citrus sinensis oil was commercially purchased from Korea and Citrus limon oil is purchased from Malaysia from local mall. On the other hand, procurement of lemon (Citrus Limon) and oranges (Citrus Sinensis) juice were purchased from local mall. The juice is squeezed from fresh fruit and stored in glass bottles in refrigerator.

\section{Source of Microbial Cultures}

Cultures were obtained from the Medical Microbiology and Parasitology research Laboratory of HUKM, Hospital Universiti Kebangsaan Malaysian. They include: three strains of Gram-positive bacteria (Staphylococcusaureus, 
Streptococcus spp, and Clostridium spp); three strains of Gram-negative bacteria (Escherichiacoli,Pseudomonas aeruginosa and Klebsiella pneumoniae). The bacterial cultures were maintained in their respective agar slants at $4^{\circ} \mathrm{C}$ throughout the course of the study and used as stock cultures. Inoculum Standardization

The test organisms were sub cultured on fresh plates of Mueller-Hinton medium and incubated for $24 \mathrm{~h}$ at $370 \mathrm{C}$. The agar plates were stored at $40 \mathrm{C}$ until required. Overnight cultures from these plates were suspended into normal saline for antimicrobial assays. They were adjusted to a turbidity matching the 0.5 McFarland standard.

\section{Antimicrobial Activity of Citrus Oil and Juice from Orange} and Lemon:

\section{Disc Diffusion Method}

Disc diffusion method for antimicrobial susceptibility testing was performed according to the standard method by "reference [3]" to assess the presence of antibacterial activities of the Citrus oil and juice. A bacterial suspension (which has been adjusted to $0.5 \mathrm{McFarland}$ standard), was used to lawn Muller Hinton agar plates evenly using a sterile swab. The plates were dried for 15 minutes at room temperature and then used for the sensitivity test. The discs which had been impregnated with a series of plant extracts were placed on the Mueller- Hinton agar surface. Each test plate includes of two discs, one negative control and one positive control. The positive control used was a standard commercial antibiotic disc.The standard antibiotic discs were ampicillin, tetracycline, streptomycin and gentamicin. For the negative control, distilled water and Tween 20 were used. Besides the controls, each plate had three treated discs placed about equidistance to each other. The plate was then incubated at $37^{\circ} \mathrm{C}$ for 18 to 24 hours depending on the species of bacteria used in the test. After the incubation, the plates were examined for inhibition zone. The inhibition zone were then measured using calipers and recorded. The tests were repeated three times to ensure reliability.

\section{Well Diffusion Method}

Screening of citrus juice and oil for antimicrobial activity was done by the agar well diffusion method [22] using microorganism cell suspension at $0.5 \mathrm{McF}$ arland standards. Each labelled medium plate was uniformly categorized with a test organism by means of sterile swab rolled in suspension and streaked on the plate surface. Wells of $5 \mathrm{~mm}$ in diameter and $2 \mathrm{~cm}$ apart were punched on the culture medium. Approximately $20 \mu \mathrm{l}$ of each extract was inoculated onto wells were made in the spread plate culture of each microbial isolates (The plates were carried out in triplicates). All plate of the tested organisms was then allowed to incubate at $37^{\circ} \mathrm{C}$ for overnight. After $24 \mathrm{~h}$ of incubation, each extract was noted for zone of inhibition for all isolates. The diameters of the zone of inhibitions were measured by measuring scale in millimeter (mm).

\section{RESULTS}

\section{Overall comparison for disc diffusion methot}

"Figure 1" indicates that all the 3 extracts showed a various wide spectrum activity against the test organisms used disc in the study. However, it was found that lemon juice had maximum inhibitory action against all the test organisms except Streptococcus pyogenes which was unaffected by lemon juice. Also it was found that lemon and sweet orange oil had minimum inhibition against all the test organisms especially with Clostridium spp which was unaffected by sweet orange oil.

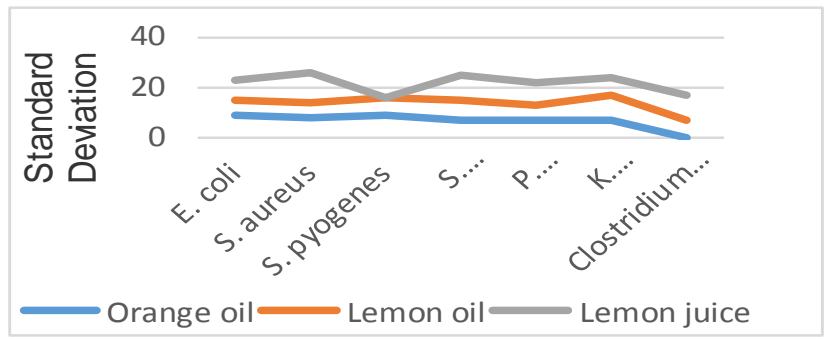

Fig. 1 Graph showing diameter of zone of inhibition (in $\mathrm{mm}$ ) with respect to the compounds against the test organisms using disc

\section{Overall comparison for well diffusion method}

"Figure 2" indicates that all the 3 compounds showed a various wide spectrum activity against the test organisms used well in the study. It was found that lemon juice had maximum inhibitory action against all the test organisms except Streptococcus pyogenes which was unaffected by lemon juice. Moreover it was found that lemon oil has shown inhibition zones with Streptococcus pneumonia and Clostridium spp. Also the sweet orange oil has shown inhibition zones with Streptococcus pyogenes and Staphylococcus aureus.

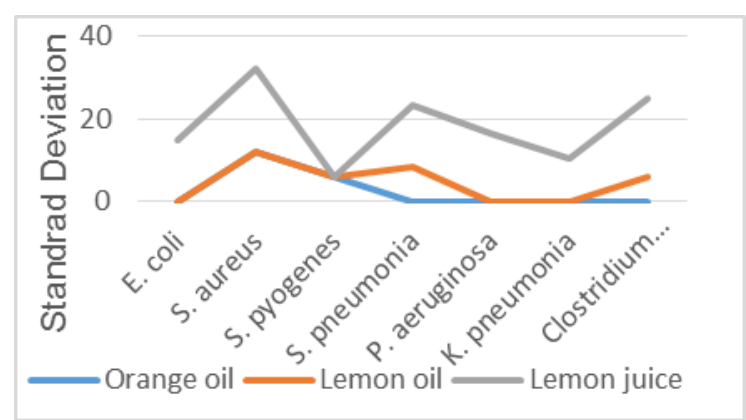

Fig 2. Graph showing diameter of zone of inhibition (in $\mathrm{mm}$ ) with respect to the 3 compounds against the test organisms using well

\section{Positive Conterol}

The positive control used was a standard commercial antibiotic disc.The standard antibiotic discs were ampicillin, tetracycline, streptomycin and gentamicin which have inhibition zone against most of bacteria strains used (Table.1).

\section{Antibacterial Activity of Citrus Oil}

Antimicrobial activity of orange and lemon oil was assessed against Escherichia coli,Staphylococcus aureus, Streptococcus pneumoniae,Pseudomonasaeruginosa, Klebsiella pneumoniae, 
Clostridium spp and Streptococcus pyogenes. The diameters of the inhibition zone are presented in Table. 2, Table. 3, Table. 4 and Table. 5.

\section{Antibacterial Activity of Orange Oil}

Orange oil disc diffusion method showed inhibition against all the Gram positive and Gram negative bacteria used in the present study except Clostridium spp which has no inhibition against orange oil disc and well method, the maximum inhibition zone was observed in Streptococcus pyogenes and minimum inhibition zone in Streptococcus pneumoniae Table. 2. By well method, only have inhibition zone against with Staphylococcus aureus, Streptococcus pyogenes was observed high and Clostridium spp shopws decreased zone of inhibition Table.3.

\section{Antibacterial Activity of Lemon Oil}

Lemon oil disc showed inhibition against all the test organisms (Gram positive and Gram negative) with maximum zone of inhibition about $10 \mathrm{~mm}$ against Klebsiella pneumoniae and minimum zone with Escherichia coli and Pseudomonas aeruginosa Table.4. For well method, inhibition zone was observed only with Streptococcus pneumoniae and Clostridium spp Table.5.

\section{Antibacterial Activity of Citrus Juice}

Bacterial activity of orange and lemon juice was examined against the wound causing bacteria as mentioned above. The results are presented in Table. 6 and Table. 7 in terms of test organisms used and the diameter of zone of inhibition.

\section{Antibacterial Activity of Lemon Juice}

Lemon juice showed inhibition against all the test organisms (Gram positive and Gram negative) with disc a maximum zone of inhibition against Staphylococcus aureus and minimum zone of inhibition against Streptococcus pyogenes Table 4.6. By well method maximum zone of inhibition against Staphylococcus aureus and minimum zone of inhibition against Streptococcus pyogenes Table 4.7. Lemon juice thus showed a wide spectrum activity against all the Gram positive and Gram negative used in the present study.

\section{Antibacterial Activity of Orange Juice}

Orange juice showed no inhibition against all the test organisms (Gram positive and Gram negative) with disc and well diffusion method. On the other hand, orange juice thus showed ineffective against all the Gram positive and Gram negative used in the present study (data not shown).
TABLE I

POSITIVE CONTROL BY STANDARD COMMERCIAL ANTIBIOTIC DISC

\begin{tabular}{|c|c|c|c|c|c|}
\hline Organisms & $\mathrm{Am}$ & $\mathrm{T}$ & S & & G \\
\hline Escherichia coli & \multicolumn{5}{|c|}{$25 \mathrm{~mm} 20 \mathrm{~mm} 30 \mathrm{~mm} \mathrm{R}$} \\
\hline Staphylococcus aureus & $10 \mathrm{~mm}$ & $\mathrm{R}$ & $20 \mathrm{mn}$ & $25 \mathrm{~mm}$ & \\
\hline Streptococcus pyorogene & $\mathrm{R}$ & \multicolumn{2}{|c|}{$30 \mathrm{~mm} \mathrm{R}$} & $\mathrm{R}$ & \\
\hline Streptococcus pneumoniae & $10 \mathrm{~mm}$ & $\mathrm{R}$ & $25 \mathrm{~mm}$ & $\mathrm{R}$ & \\
\hline Pseudomonas aeruginosa & $\mathrm{R}$ & $\mathrm{R}$ & $\mathrm{R}$ & & $20 \mathrm{~mm}$ \\
\hline Klebsiell pneumoniae & $\mathrm{R}$ & $\mathrm{R}$ & $\mathrm{r}$ & & $35 \mathrm{~mm}$ \\
\hline Clostridium spp & $5 \mathrm{~mm}$ & $\mathrm{R}$ & $\mathrm{R}$ & & $25 \mathrm{~mm}$ \\
\hline
\end{tabular}

R: Resistant, Am: Ampicillin,T: Tetracycline,S: Streptomycin, G: Gentamicin

TABLE II

SHOWING DIAMETER OF ZONE OF INHIBITION (IN MM) OF ORANGE OIL (DISC METHOD) AGAINST CLINICAL ISOLATES FROM WOUND INFECTION

\begin{tabular}{lccccc}
\hline Organisms & $\begin{array}{c}\text { Diameter of Zone of } \\
\text { inhibition with orange oil } \\
\text { (in mm) }\end{array}$ & $\begin{array}{c}\text { Me an } \pm \text { S.D } \\
\text { (in mm) }\end{array}$ \\
\hline Escherichia coli & 8 & 9 & 9 & $8.66 \pm 0.75$ \\
Staphylococcus aureus & 6 & 8 & 8 & $7.33 \pm 1.15$ \\
Streptococcus. Pyogenes & 9 & 10 & 8 & $9 \pm 1.0$ \\
Streptococcus pneumonia & 6 & 8 & 6 & $6.6 \pm 1.1$ \\
Pseudomonas aeruginosa & 7 & 7 & 7 & $7 \pm 0.0$ \\
Klebsiella pneumonia & 7 & 7 & 7 & $7 \pm 0.0$ \\
Clostridium spp & 0 & 0 & 0 & 0.0 \\
\hline
\end{tabular}

TABLE III

SHOWING DIAMETER OF ZONE OF INHIBITION (IN MM) OF ORANGE OIL (WELL METHOD) AGAINST CLINICAL ISOLATES FROM WOUND INFECTION

\begin{tabular}{lcccc}
\hline Organisms & $\begin{array}{c}\text { Diameter of Zone of } \\
\text { inhibition with orange oil } \\
\text { (in mm) }\end{array}$ & $\begin{array}{c}\text { Me an } \mathbf{\text { S.D }} \\
\text { (in mm) }\end{array}$ \\
\hline Escherichia coli & 0 & 0 & 0 & 0.0 \\
Staphylococcus aureus & 11 & 10 & 12 & $12 \pm 02.64$ \\
Streptococcus pyogenes & 6 & 6 & 6 & $6 \pm 0.0$ \\
Streptococcus pneumonia & 0 & 0 & 0 & 0.0 \\
Pseudomonas aeruginosa & 0 & 0 & 0 & 0.0 \\
Klebsiella pneumonia & 0 & 0 & 0 & 0.0 \\
Clostridium spp & 0 & 0 & 0 & $7 \pm 0.0$ \\
\hline
\end{tabular}

SHOWING DIAMETER OF ZONE OFINHIBITION (INMAC) WIIH RESP TO LEMON OIL USING DISC

\begin{tabular}{|c|c|c|}
\hline ORGANISM & $\begin{array}{l}\text { DIAMETER OF ZONE OF } \\
\text { INHIBIMON WITH LEMON } \\
\text { OII (NN MM) }\end{array}$ & $\begin{array}{c}\text { ME AN }=\text { SD } \\
\text { (IN MAM) }\end{array}$ \\
\hline ESCHERICHIA COLI & 666 & $6 \pm 0.0$ \\
\hline STAPHYLOCOCCUS ALREUS & 677 & $6.66 \pm 0.57$ \\
\hline STREPTOCOCCUS & 777 & $7 \pm 0.0$ \\
\hline PYOGENES & 887 & $7.66 \pm 0.57$ \\
\hline STREPTOCOCCUS & $\begin{array}{lll}6 & 5 & 7\end{array}$ & $6 \pm 1.0$ \\
\hline PNEUMONIA & 91010 & $9.66 \pm 0.57$ \\
\hline PSEUDOMONAS & 777 & $7 \pm 0.0$ \\
\hline \multicolumn{3}{|l|}{ AERUGLNOSA } \\
\hline \multicolumn{3}{|l|}{ KLEBSIELLA PNEUMONIA } \\
\hline CLOSTRMIUMISPP. & & \\
\hline
\end{tabular}


TABLE V

SHOWING DIAMETER OF ZONE OF INHIBITION (IN MM) WITH RESPECT TO LEMON OIL USING WELL

\begin{tabular}{|c|c|c|}
\hline Organisms & $\begin{array}{l}\text { Diameter of Zone of } \\
\text { inhibition with lemon } \\
\text { oil (in mm) }\end{array}$ & $\begin{array}{l}\text { Me an } \pm \\
\text { S.D (in } \\
\text { mm) }\end{array}$ \\
\hline Escherichia coli & $\begin{array}{lll}0 & 0 & 0\end{array}$ & 0.0 \\
\hline Staphylococcus aureus & $\begin{array}{lll}0 & 0 & 0\end{array}$ & 0.0 \\
\hline Streptococcus pyogenes & $\begin{array}{lll}0 & 0 & 0\end{array}$ & 0.0 \\
\hline Streptococcus pneumonia & 1087 & $8.33 \pm 1.52$ \\
\hline Pseudomonas aeruginosa & $\begin{array}{lll}0 & 0 & 0\end{array}$ & 0.0 \\
\hline Klebsiella pneumonia & $\begin{array}{lll}0 & 0 & 0\end{array}$ & 0.0 \\
\hline Clostridium spp & 666 & $6 \pm 0.0$ \\
\hline
\end{tabular}

TABLE VI

SHOWING DIAMETER OF ZONE OF INHIBITION (IN MM) WITH RESPECT TO LEMON JUICE USING DISC

\begin{tabular}{|c|c|c|}
\hline Organisms & $\begin{array}{c}\text { Diameter of Zone of } \\
\text { inhibition with lemon } \\
\text { juice (in mm) }\end{array}$ & $\begin{array}{l}\text { Me an } \pm \text { S.D } \\
\quad \text { (in mm) }\end{array}$ \\
\hline Escherichia coli & $\begin{array}{lll}9 & 8 & 8\end{array}$ & $8.33 \pm 0.57$ \\
\hline Staphylococcus aureus & 121212 & $12 \pm 0.0$ \\
\hline Streptococcus pyogenes & $\begin{array}{lll}0 & 0 & 0\end{array}$ & 0.0 \\
\hline Streptococcus pneumonia & 11119 & $10.33 \pm 1.15$ \\
\hline Pseudomonas aeruginosa & 7108 & $8.33 \pm 1.52$ \\
\hline Klebsiella pneumonia & $\begin{array}{lll}6 & 7 & 7\end{array}$ & $6.66 \pm 0.57$ \\
\hline Clostridium spp & 1099 & $9.33 \pm 0.57$ \\
\hline
\end{tabular}

TABLE VII

SHOWING DIAMETER OF ZONE OF INHIBITION (IN MM) WITH RESPECT TO LEMON JUICE USING WELL

\begin{tabular}{lcc}
\hline Organisms & $\begin{array}{c}\text { Diameter of Zone of } \\
\text { inhibition with lemon } \\
\text { juice (in mm) }\end{array}$ & $\begin{array}{c}\text { Me an } \pm \\
\text { S.D (in } \\
\text { mm) }\end{array}$ \\
\hline Escherichia coli & 151415 & $14.66 \pm 0.57$ \\
Staphylococcus aureus & 182121 & $20 \pm 1.73$ \\
Streptococcus pyogenes & 000 & 0.0 \\
Streptococcus pneumonia & 161514 & $15 \pm 1$ \\
Pseudomonas aeruginosa & 171517 & $16.33 \pm 1.15$ \\
Klebsiella pneumonia & 11119 & $10.33 \pm 1.15$ \\
Clostridium spp & 202116 & $19 \pm 2.64$ \\
\hline
\end{tabular}

\section{DISCUSSION}

\section{Positive Control}

The positive control indicates that all the antibiotics tested such as ampicillin, tetracycline, streptomycin and gentamicin showed inhibition against Gram positive and Gram negative bacteria. However it was found that gentamicin was most effective against most of the organisms used in the present study.

\section{Negative Control}

Negative control by using distilled water and Tween 20 showed no inhibition against all the test organisms.

\section{Antibacterial Activity of Citrus Oil Using Disc Method}

The oils of Citrus sinensis and Citrus limon were found to be equally effective against both groups of bacteria (Gram positive and negative), except Clostridium spp which was found no inhibition with Citrus sinensis oil. However, Clostridium spp with Citrus limon oil had inhibitory zone (7士0mm). On the other hand, Escherichia coli, Staphylococcus aureus, Streptococcus pyogenes and Pseudomonas aeruginosa with Citrus sinensis oil showed higher inhibitory zones than Citrus limon oil $(8.66 \pm 0.75)$, (7.33 \pm 1.15$),(9 \pm 1)$ and $(7 \pm 0)$ respectively. But Streptococcus pneumonia and Klebsiella pneumonia with Citrus limon oil have shown higher inhibitory zones than Citrus sinensis oil (7.66 \pm 0.57$)$ and $(9.66 \pm 0.57)$ respectively.This result suggests the effect of antibacterial activity of Citrus sinensis and Citrus limon oil against clinical isolates, similar to previous finding that reported orange oil using well diffusion method [15] Another study with orange and lemon oil, had higher inhibitory zones compared to this study [20]. Previous studies indicated that S. aureus presented a variable sensitivity to different citrus EOs species [4].

\section{Antibacterial Activity Of Citrus Juice}

The juice from Citrus limon exhibited inhibitory activities against Gram positive and Gram negative bacteria in using the disc diffusion method except for Streptococcus pyogenes. With limon juice, maximum inhibition zone was observed with Staphylococcus aureus (12 \pm 0$)$ and minimum inhibition zone with Klebsiell pneumoniae (6.66 \pm 0.57$)$. Our result correcte with [2]. Previous studies have shown lemon extract to have significant antimicrobial activity against Staphylococcus aureus, Klebsiella pneumoniae, Escherichia coli and Pseudomonas aeruginosa [7]. However Citrus sinensis extract showed no inhibition shown activities against Gram positive and Gram negative using the disc diffusion method, similar as other studies [5], [8], [12].

\section{Antibacterial Activity of Citrus Oil Using Well Method}

Antibacterial activities from Citrus sinensis and Citrus limon oil were carried out against Gram positive and Gram negative bacteria using the well diffusion method. The Citrus sinensis showed no inhibition zones against both groups of bacteria (Gram positive and negative) except for Staphylococcus aureus, which has moderate inhibition zones (12 \pm 2.64$)$ and Streptococcus pyogenes minimum inhibition zones $(6 \pm 0)$. For citrus limon oil, no inhibition zones against both groups of bacteria (Gram positive and negative) except Streptococcus pneumonia $(8.33 \pm 1.52)$ and Clostridium spp $(6 \pm 0)$. Studies by "reference [15]" has showed orange oil had antibacterial activity on Staphylococcus aureus. Another study has shown high and moderate inhibition zones with Citrus sinensis and Citrus limon oil [20]. 


\section{Antibacterial Activity of Citrus Juice}

The juice from Citrus limon juice exhibited inhibitory activities against Gram positive and Gram negative using the well diffusion method except with Streptococcus pyogenes. Furthermore, with limon juice the maximum inhibition zone was observed in Staphylococcus aureus $(20 \pm 1.73)$ and the minimum inhibition zone was observed in Klebsiella pneumoniae $(10.33 \pm 1.15)$. Previous studies also indicated C.limon had good inhibition zone against Staphylococcus aureus [2]. Moreover, investigation on antimicrobial properties of lemon has shown lemon has significant antimicrobial activity against Staphylococcus aureus Klebsiell pneumoniae, Escherichia coli and Pseudomonas aeruginosa, especially for S. aureus [7]. In this study, Citrus sinensis (orange juice) showed no inhibition against the bacteria tested. This result is similar to another study which indicated that Citrus sinensis had no inhibition activities against Gram positive and Gram negative using the well diffusion method [5], [8], [12]. In contrast, there are findings on positive antibacterial activity of orange against bacteria [11], [14]. Lemon played a significant role as antimicrobial agents as they are natural, cheap, safe, and as an alternative therapy to common antibiotic. Furthermore, difference between Citrus sinensis and Citrus limon antibacterial effect could be due to difference in the phytochemical components in various part of the plant or may be also due to the Citrus used and/or environmental factors or difference in the genotypes of the Citrus plant [21]. Also for the various sensitivity of the Gramnegative bacteria compared to that of Gram-positive bacteria may be because differences in their cell wall components. Gram-positive bacteria contain an outer peptidoglycan layer, which acts important role as a permeability barrier, whereas Gram-negative bacteria have an outer phospholipid membrane [18].

\section{CONCLUSION}

The present study is to investigate the antibacterial activity of orange oil, lemon oil, orange juice and lemon juice against bacteria using disc method and well method. The overall result clearly showed that disc method offered a more efficient way to investigate antibacterial effect of Citrus. And for the two different type of citrus content tested in juice and oil solutions, it was observed juice had better inhibition zone compared to oil base. Lastly, it was found lemon juice (Citrus limon) had overall better antibacterial activity compared to orange juice (Citrus sinensis).

\section{ACKNOWLEDGMENTS}

i. The mechanism of action of extract citrus juice/oil and their major components at high level should be investigated.

ii. Isolation and purification of major components from extract citrus juice/ oil should be performed.

iii. Safety studies for using extract citrus juice/oil in greater concentration should be determined.

\section{REFERENCES}

[1] AronsonJ.K.,NaturePublishingGroup.Retrievedfromhttp://

medicine .nature.com. (2001).

[2] Al-Ani, W. N., Al-Haliem, S. M., \&Tawfik,N.O.(2009).Evaluationof the antibacterial activity of citrus juices: An in vitro study. Al-Rafidain Dent J, 10(2), 376-382.

[3] Bauer,A.W.,Kirby,W.M.M.,Sherris,J.C.,\&Turck,M.(1966).Antibiotcsusce ptibility testing by a standardized single disk method. American journal of clinical pathology, 45(4), 493.

[4] De Billerbeck, V. G. (2007). Huiles essentielles et bactéries résistantes aux antibiotiques. Phytothérapie, 5(5), 249-253. https://doi.org/10.1007/s10298-007-0265-z

[5] Eloff, J. N. (1998). Which extract should be used for the screening and isolation of antimicrobial components from plants? Journal of ethnopharmacology, 60(1), 1-8. https://doi.org/10.1016/S0378-8741(97)00123-2

[6] Farag R.S., Daw Z.Y., Hewedi F.M. and El-Baroty G.S (2009). Antimicrobial activity of some. Egyptian spice essential oils. J. Food Prot., 72: 665-667.

[7] Hayes, A. J., \& Markovic, B. (2002). Toxicity of Australian essential oil Backhousia citriodora (Lemon myrtle). Part 1. Antimicrobial activity and in vitro cytotoxicity. Food and Chemical Toxicology, 40(4), 535-543. https://doi.org/10.1016/S0278-6915(01)00103-X

[8] Hussain, K. A., Tarakji, B., Kandy, B. P. P., John, J., Mathews, J., Ramphul, V., \& Divakar, D. D. (2015). Antimicrobial effects of citrus sinensis peel extracts against periodontopathic bacteria: an in vitro study. Roczniki Państwowego Zakładu Higieny, 177(2).

[9] Kawaii, S., Tomono, Y., Katase, E., Ogawa, K., Yano, M., Koizumi, M., \& Furukawa, H. (2000). Quantitative study of flavonoids in leaves of Citrus plants. Journal of agricultural and food chemistry, 48(9), 3865-3871. https://doi.org/10.1021/jf000100o

[10] Mohanapriya, M., Ramaswamy, D. L., \& Rajendran, D. R. (2013). Health and Medicinal properties of Lemon (CITRUS LIMONUM). International Journal of Ayurvedic and Herbal Medicine, 3(1), 1095-1100.

[11] Nair, R., KALARIYA, T., \& Chanda, S. (2005). Antibacterial activity of some selected Indian medicinal flora. Turkish Journal of Biology, 29(1), 41-47.

[12] Nagarajappa, R., Batra, M., Sharda, A. J., Asawa, K., Sanadhya, S., Daryani, H., \& Ramesh, G. (2014). Antimicrobial Effect of Jasminum grandiflorum L. and Hibiscus rosa-sinensis L. Extracts against Pathogenic Oral Microorganisms--An In Vitro Comparative Study. Oral health \& preventive dentistry, 13(4), 341-348.

[13] Nascimento, G. G., Locatell, J., Freitas, P. C., \& Silva, G. L. (2000). Antibacterial activity of plant extracts and phytochemicals on antibioticresistant bacteria. Brazilian journal of microbiology, 31(4), 247-256 https://doi.org/10.1590/S1517-83822000000400003

[14] Nisha, S. N., Swedha, A. A., \& Rahaman, J. S. N. (2013). Antibacterial activity of citrus sinensis peel against enteric pathogens. IJPRBS, 2(5), 1-13.

[15] Obidi, O. F., Adelowotan, A. O., Ayoola, G. A., Johnson, O. O., Hassan, M. O., \& Nwachukwu, S. C. U. (2013). Antimicrobial Activity of Orange Oil on Selected Pathogens.119

[16] Rojas, A., Hernandez, L., Pereda-Miranda, R., \& Mata, R. (1992). Screening for antimicrobial activity of crude drug extracts and pure natural products from Mexican medicinal plants. Journal of ethnopharmacology, 35(3), 275-283. https://doi.org/10.1016/0378-8741(92)90025-M

[17] Rojas A., Hernandez L, Pereda-Miranda R., Meta R. (2003). Screening of antimicrobial activity of Crude drug extracts and pure natural products from mexican medicinal plants. Journal of Ethnopharmacology 35, 275-283. https://doi.org/10.1016/0378-8741(92)90025-M

[18] Samarakoon, K., Senevirathne, M., Lee, W. W., Kim, Y. T., Kim, J. I., Oh, M. C., \& Jeon, Y. J. (2012). Antibacterial effect of citrus press-cakes dried by high speed and far-infrared radiation drying methods. Nutrition research and practice, 6(3), 187-194. https://doi.org/10.4162/nrp.2012.6.3.187

[19] Shahnah, S. M., Ali, S., Ansari, H., \& Bagri, P. (2007). New sequiterpene derivative from fruit peel of citrus limon (Linn) Burn. F. Sci. Pharm, 75, 165- 170 .

https://doi.org/10.3797/scipharm.2007.75.165

[20] Shalu Hasija, Geeta Ibrahim,and Ashok Wadia. (2015). Antimicrobial Activity of Citrus Sinensis (Orange), Citrus Limetta (Sweet Lime) and Citrus Limon (Lemon) Peel Oil on Selected Food Borne Pathogens, pp: 35-39.

[21] Tumane, P. M., Meshram,V. G., \& Wasnik, D. D. (2014). Comparative study of 
antibacterial activity of peel extracts of citrus aurantium L.(Bitter orange) and Citrus medica L.(Lemon) against clinical isolates from wound infection.Int $\mathbf{J}$ Pharm Bio Sci, 5(1), 382-387.

[22] Thitiertdecha, N., Teerawutgulrag, A., \& Rakariyatham, N. (2008). Antioxidant and antibacterial activities of Nephelium lappaceum L. extracts.LWT-Food Science and Technology, 41(10), 2029-2035. https://doi.org/10.1016/j.Iwt.2008.01.017 